\title{
The Genetic Relationship of Vietnamese Pigs in Central Highlands Assessed by Cytochrome b
}

\author{
Le Thanh Long ${ }^{* \#}$, Nguyen Thi Phuong $\mathrm{Mai}^{2 *}$, Doan Chinh Chung ${ }^{3}$, Do Minh $\mathrm{Si}^{3}$, \\ Ho Nguyen Quynh Chi' ${ }^{1}$, Hoang Nghia Son ${ }^{1}$ \\ ${ }^{1}$ Institute of Tropical Biology, Viet Nam Academy of Science and Technology, Ho Chi Minh City, Vietnam \\ ${ }^{2}$ Tay Nguyen Institute for Scientific Research, Viet Nam Academy of Science and Technology, Da Lat City, \\ Vietnam \\ ${ }^{3}$ University of Science, Ho Chi Minh City, Vietnam \\ Email: "lelong2510@gmail.com
}

Received 27 May 2014; revised 26 June 2014; accepted 25 July 2014

Copyright (C) 2014 by authors and Scientific Research Publishing Inc. This work is licensed under the Creative Commons Attribution International License (CC BY). http://creativecommons.org/licenses/by/4.0/

\section{(c) (i) Open Access}

\section{Abstract}

To estimate the genetic relationship of Vietnamese pigs in Central Highlands, we compared cytochrome b sequences of Vietnamese wild boars and Vietnamese domestic pigs with other Asian and European wild boars. The results showed that there were two wild boar populations locating in Vietnam Central Highlands including wild boars of group I and wild boars of group II. The Vietnamese wild boars of group II and domestic pigs were genetically close to Asian A1 and Asian A2 wild boar groups, whereas the Vietnamese wild boars of group I were genetically distinct from Asian A1, Asian A2 wild boar groups. The phylogenetic tree demonstrated that the Vietnamese wild boars of group I were clustered in one clade which was distinct from Asian wild boars and Europe wild boars. In addition, the Vietnamese wild boars of group I were estimated to have diverged from European wild boars at 421500 YBP, indicating that Vietnamese wild boar of group I could be isolated from other Asian wild boars. The single nucleotide polymorphism analysis showed that three Asian haplotypes were contributed in Vietnamese wild boars including A3 (TATG) haplotype in Vietnamese wild boar of group I and A1 (CATA) haplotype and A2 (CATG) haplotype in Vietnamese wild boars of group II. The A1 haplotype and A2 haplotype were also distributed in Vietnamese domestic pigs. Thus, there is a high possibility that Vietnam Central Highlands is a principal source for research on genetic diversity in Asian wild boar and domestic pig populations.

\footnotetext{
*These authors equally contributed to this work.

${ }^{\#}$ Corresponding author.
} 


\section{Keywords}

\section{Cytochrome b, Domestic Pig, Genetic Relationship, Vietnam Central Highlands, Wild Boar}

\section{Introduction}

Mitochondrial DNA has been used to perform phylogenetic studies in animal species. One of the regions of mtDNA used when establishing phylogenetic relationships among various species, and in species identification, is a fragment of the gene coding cytochrome b [1]. In pigs (Sus), genetic variability in cytochrome $\mathrm{b}$ has been applied as a tool to assess the genetic relationship among various breeds and populations [2]. Moreover, mitochondrial DNA data revealed multiple centers of domestication across Eurasia [3] and phylogenetic analysis of porcine mtDNA demonstrated that Asian groups and European groups diverged well with divergence time 900000 YBP [4] [5].

Vietnam located in the region known as Indo-Burma Biodiversity Hospot which has the remarkable peculiarity of porcine populations. The most of Indo-Burma region placed in the Southeast Asia which maybe considered the homeland of Sus genus, as 6 out of 8 species are endemic to this area [6]. The previous study genetically characterized some indigenous pig breeds in the Northern of Vietnam using microsatellites [7]. The Vietnamese autochthonous breeds showed higher degrees of polymorphism, allelic diversity, and heterozygosity than the other pig breeds. Also, large genetic diversity was observed across the area of distribution, with villagespecific subpopulations, which led to significant inbreeding coefficients. Another study showed that the D-loop sequences of Vietnamese indigenous domestic pigs in the Northern of Vietnam were extremely diverse and were thought to have contributed to the diversity of mtDNA among East Asian domestic pigs [8]. Furthermore, Vietnamese domestic pigs were founded to be belonged to haplogroups presented in the Mekong region [9]. However, the genetic relationship of Vietnamese domestic pig and wild boar populations have been poorly characterized in other areas of Vietnam; especially, the distribution of Asian haplotype or European haplotype in Vietnamese pigs was still unknown. In the present study, we aimed to compare sequences of Vietnamese pigs from the Vietnam Central Highlands with Asian and European wild boars and assess the genetic relationship based on cytochrome b. The Asian and European haplotypes distribution in Vietnamese wild boars and domestic pigs was also estimated.

\section{Material and Methods}

\subsection{DNA Sampling}

Vietnamese wild boars (Sus scrofa) and domestic pigs (Sus scrofa domesticus) were used for this study (Table 1). The distribution of Vietnamese pigs was demonstrated in Figure 1. All collected samples were got permission from the local authorities and relative permits. The samples were kept in $-20^{\circ} \mathrm{C}$ and transported to the laboratory. The remainders of sequences were derived from GenBank.

\subsection{DNA Extraction}

Total DNA from Vietnamese pigs were extracted from ear tissues. Tissue samples were digested by digestion buffer (10 mM Tris-HCl, $10 \mathrm{mM} \mathrm{NaCl}, 25 \mathrm{mM}$ EDTA and 1\% sodium dodecyl sulfate) with proteinase $\mathrm{K}$ (1 $\mathrm{mg} / \mathrm{ml}$ ) [10]. DNA was extracted using phenol:chloroform:isoamylalcohol 25:24:1 and precipitated by ethanol. Total DNA was resuspended with TE buffer $(0.1 \mathrm{mM}$ Tris- $\mathrm{HCl}$ and $0.1 \mathrm{mM}$ EDTA $)$ and preserved at $-20^{\circ} \mathrm{C}$.

\subsection{PCR Conditions}

Cytochrome b sequences were amplified with primers in Table 2 [11]. PCR was performed in a final volume of $50 \mu \mathrm{l}$ containing $5 \mu \mathrm{l}$ 10X PCR Buffer, $1.5 \mathrm{mM} \mathrm{MgCl}$, $200 \mu \mathrm{M}$ dNTP, 0.05 units/ $\mu \mathrm{l}$ Taq DNA Polymerase, 0.5 $\mu \mathrm{M}$ Forward and Reverse Primer. PCR cycle was performed under the following conditions: one cycle of DNA denaturation at $94^{\circ} \mathrm{C}$ in $5 \mathrm{~min} ; 40$ cycles at $94^{\circ} \mathrm{C}$ in $30 \mathrm{~s}$; annealing at $55^{\circ} \mathrm{C}$ in $45 \mathrm{~s}$; extension at $72^{\circ} \mathrm{C}$ in $45 \mathrm{~s}$; final extension at $72^{\circ} \mathrm{C}$ in $10 \mathrm{~min}$. A single band of was visualized following electrophoresis of the reaction product in a $1 \%$ agarose gel. 
Table 1. Distribution of Vietnamese pigs in Central Highlands.

\begin{tabular}{ccc}
\hline Animals & Distribution & Type \\
\hline VWB1 - VWB11 & Bidoup-NuiBa national park (Lam Dong province) & Wild boar \\
VWB12 - VWB13 & Bao Loc city (Lam Dong province) & Wild boar \\
VWB14 - VWB16 & Buon Ma Thuot city (Dak Lak province) & Wild boar \\
VWB17 - VWB20 & Kon Tum city (Kon Tum province) & Wild boar \\
VDP1 - VDP9 & Da Huai district (Lam Dong province) & Domestic pig \\
VDP10 - VDP13 & Buon Ho district (Dak Lak province) & Domestic pig \\
VDP14 - VDP17 & Pleiku city (Gia Lai province) & Domestic pig \\
\hline
\end{tabular}

Table 2. Primer pairs used for PCR amplification and sequencing of cytochrome b.

\begin{tabular}{ccrc}
\hline Gene & Position & 5' to 3' primer pair sequences, forward/reverse & Size, bp \\
\hline CytB1 & 14113 to 14745 & CACGACCAATGACATGAAAAATC/GCTGCGAGGGCGGTAAT & 635 \\
CytB2 & 14697 to 15357 & TCTTCGCCTTCCACTTTATCCTG/TGGCCCTCCTTTTCTGGTTTA & 661 \\
\hline
\end{tabular}
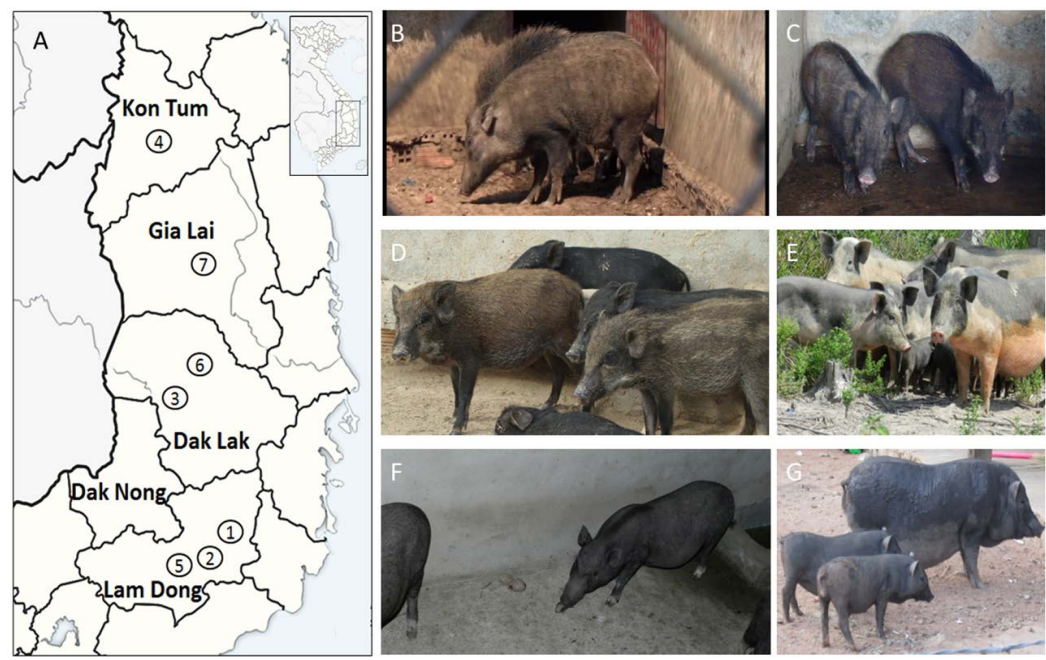

Figure 1. (A) Sample collecting positions (1: Bidup-NuiBa national park, 2: Bao Loc city, 3: Buon Ma Thuot city, 4: Kon Tum city, 5: Da Huai district, 6: Buon Ho district, 7: Pleiku city); (B) (C) Vietnamese wild boars of group I; (D) Vietnamese wild boars of group II; (E)-(G) Vietnamese domestic pigs.

\subsection{Sequencing and Data Analysis}

PCR products were purified using ExoSAP-IT PCR Clean up kit and used as sequencing templates. The nucleotide sequences were determined using the 3730XL DNA Analyzer. The comparison of cytochrome $b$ sequences was performed for 37 Vietnamese pigs and other Asian wild boars and European wild boars (AF136541AF136554, AF163099, AF163100) [12]. The cytochrome b sequences were aligned using CLUSTAL W [13]. Tamura \& Nei model was used as a genetic distance model. Neighbor-joining method was applied for phylogenetic construction [14]. Bootstrap analyses (using 1000 replications) were used to assess the confidence in branching order.

\section{Results}

\subsection{Sequence Variation in Cytochrome b}

Analysis of cytochrome b sequences of 37 Vietnamese pigs (including 20 wild boars and 17 domestic pigs), Asian wild boars, and European wild boars showed 46 polymorphic sites (Figure 2), representing $4.4 \%$ of the 


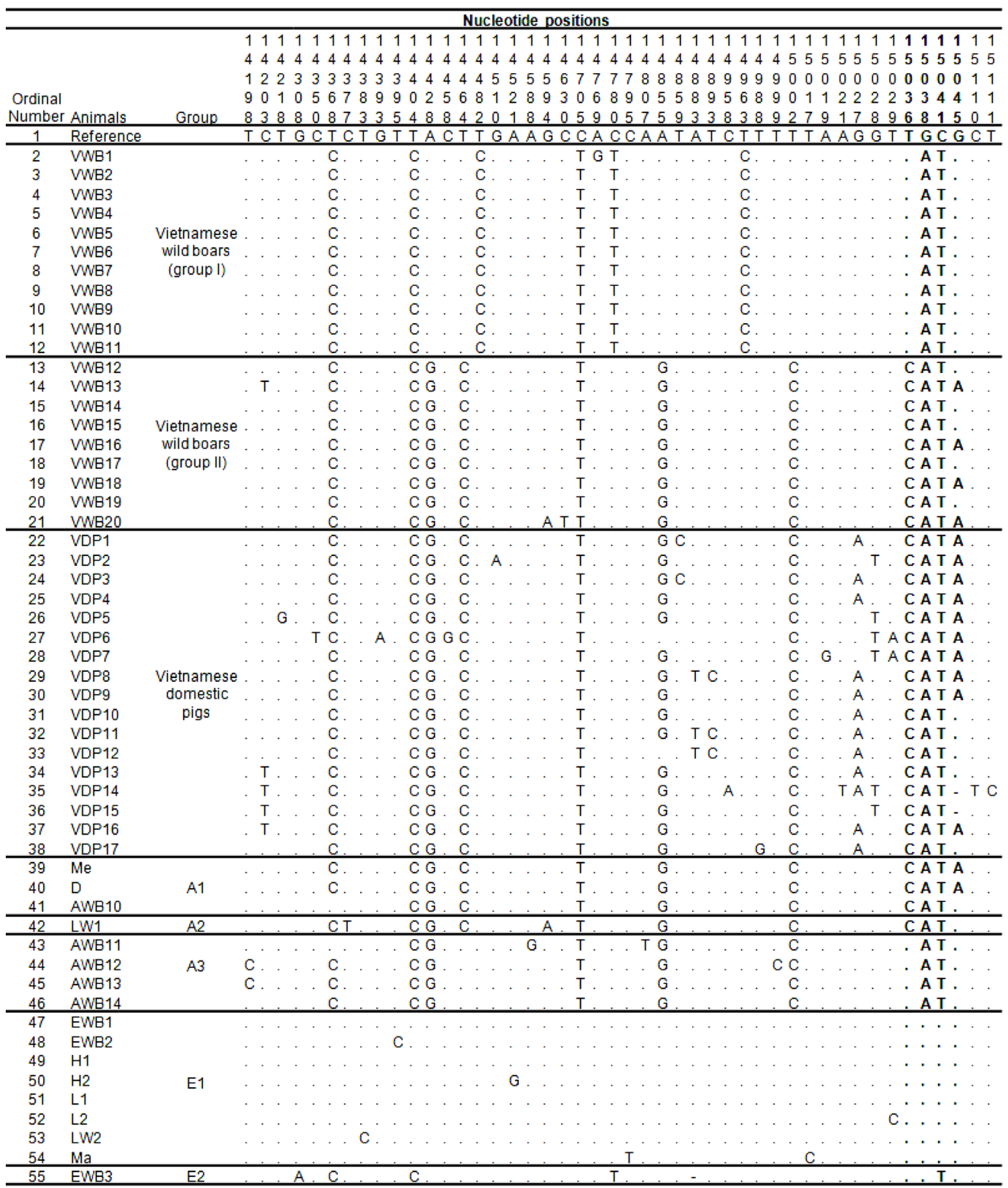

Figure 2. Variable positions of the cytochrome b gene in wild boars and domestic pigs. Sequence identities are indicated by dots. Single nucleotide polymorphism positions are bold. The Sus scrofa mitochondrion genome (accession number: NC_000845) was used as the reference sequence.

total DNA sequence analyzed (1040 bp). A highly variable region was found between positions 15000 and 15100 with the substitution rate of $11 \%, 2.5$ times than the overall substitution rate (4.4\%). Vietnamese wild boars were separated into group I (haplotype VWB1 - VWB11) and group II (haplotype VWB12 - VWB20) basing on 8 variable positions (14428, 14464, 14482, 14780, 14855, 14963, 15002, and 15036) (Figure 2). Thus, there were at least two genetically distinct wild boar populations in the Central Highlands of Vietnam The vari- 
able positions of Vietnamese wild boars of group II and domestic pigs were identical to Asian wild boars of calling clade A1 (including haplotype D, Me, and AWB10). Three newly variable positions of Vietnamese wild boars in group I were found to be distinct to other Asian wild boars and European wild boars at position 14482, 14780, and 14963, suggesting that these single nucleotide substitutions could be diagnostic for distinguishing Vietnamese wild boars of group I and other wild boars of Asian or European clade.

\subsection{Phylogenetic Relationship}

The genetic distance between groups was calculated based on the maximum-likelihood method showed that all haplotypes of Vietnamese wild boars of group I (mean \pm s.e., $0.0002 \pm 0.0002$ within group), all haplotypes of Vietnamese wild boars of group II ( $0.0008 \pm 0.0004$ within group), and all haplotypes Vietnamese domestic pigs $(0.0042 \pm 0.0011)$ formed three distinct clusters that are well separated from each other (Table 3). The distance between Vietnamese wild boars of group II and clade A1 wild boars $\left(2 \times 10^{-5} \pm 3 \times 10^{-6}\right)$, and between Vietnamese domestic pigs and clade A1 wild boars $(0.0008 \pm 0.0006)$ was shorter than the distance between Vietnamese wild boars of group I and clade A1 wild boars $(0.0095 \pm 0.0034)$. Moreover, the distance between Vietnamese wild boars of group I and Vietnamese wild boars of group II $(0.0095 \pm 0.0034)$, and distance between Vietnamese wild boars of group I and Vietnamese domestic pigs (0.0101 \pm 0.0034$)$ were almost equal to the distance between Vietnamese wild boars of group I and clade A1 wild boars. Thus, Vietnamese wild boars of group II and Vietnamese domestic pigs are closely related to clade A1 wild boars. Vietnamese wild boars of group I was closer to clade A3 wild boars than other Asian wild boars group (0.0073 \pm 0.0029$)$. Almost the distance between Vietnamese pigs and Asian wild boars were shorter than the distance between Vietnamese pigs and European wild boars.

The neighbor-joining tree was applied to assess the phylogenetic relationship of Vietnamese pigs, Asian wild boars and European wild boars (Figure 3). Haplotypes clustered into three lineages: Vietnamese wild boars of group I with 95\% bootstrap probability, European wild boars (including E1 and E2) with 64\% bootstrap probability, and another clade (including Asian wild boars, Vietnamese wild boars of group I, and Vietnamese domestic pigs) with 92\% bootstrap probability. Haplotypes of Vietnamese wild boars of group II and domestic pigs located in the same group with clade A1 wild boars with 71\% bootstrap probability. All 17 Vietnamese domestic pigs were clustered in one clade with $19 \%$ bootstrap probability that was distinct to clade of Vietnamese wild boars of group II with $11 \%$ bootstrap probability. Vietnamese wild boars of group I placed on near clade A3 wild boars in comparing to other Asian wild boars.

Table 3. Matrix of Tamura \& Nei genetic distance among wild boars and domestic pigs. Lower triangular matrix values were mean genetic distances, Upper triangular matrix values were standard errors.

\begin{tabular}{|c|c|c|c|c|c|c|c|c|}
\hline & 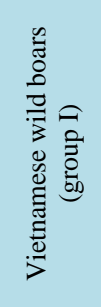 & 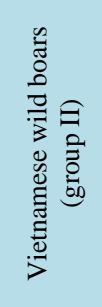 & 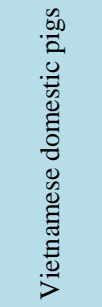 & 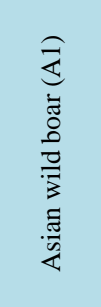 & 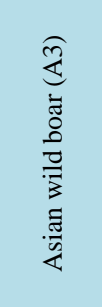 & 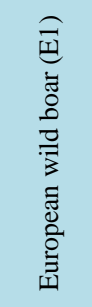 & 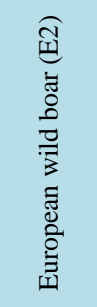 & 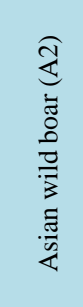 \\
\hline Vietnamese wild boars (group I) & & 0.0034 & 0.0034 & 0.0034 & 0.0029 & 0.0032 & 0.0026 & 0.0038 \\
\hline Vietnamese wild boars (group II) & 0.0095 & & 0.0006 & 0.0000 & 0.0016 & 0.0037 & 0.0037 & 0.0015 \\
\hline Vietnamese domestic pigs & 0.0101 & 0.0007 & & 0.0006 & 0.0017 & 0.0037 & 0.0037 & 0.0017 \\
\hline Asian wild boar (A1) & 0.0095 & 0.0000 & 0.0008 & & 0.0016 & 0.0035 & 0.0037 & 0.0016 \\
\hline Asian wild boar (A3) & 0.0073 & 0.0026 & 0.0034 & 0.0024 & & 0.0032 & 0.0033 & 0.0021 \\
\hline European wild boar (E1) & 0.0095 & 0.0119 & 0.0125 & 0.0111 & 0.0091 & & 0.0026 & 0.0040 \\
\hline European wild boar (E2) & 0.0059 & 0.0107 & 0.0113 & 0.0107 & 0.0085 & 0.0059 & & 0.0040 \\
\hline Asian wild boar (A2) & 0.0119 & 0.0021 & 0.0032 & 0.0024 & 0.0049 & 0.0143 & 0.0131 & \\
\hline
\end{tabular}




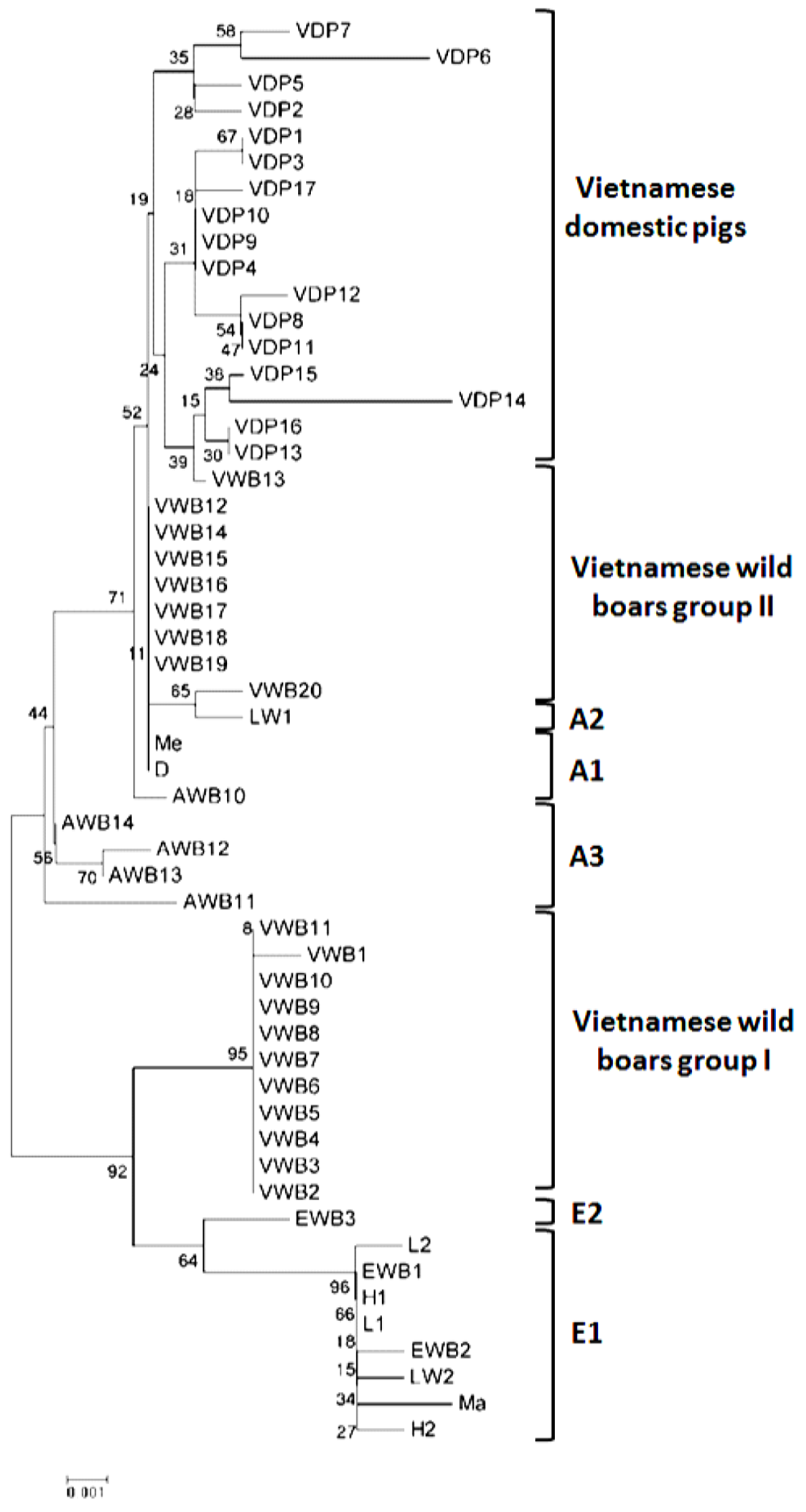

Figure 3. Phylogenetic tree constructed from cytochrome b sequences of wild boars and domestic pigs by the neighbor-joining analysis method. Bootstrap resampling was done 1000 times, and resulting bootstrap values are shown on the corresponding branches. 


\section{Discussion}

Vietnamese pigs in Central Highland were not genetically characterized. Analysis of variable positions and phylogenetic relationship showed that there were at least three Vietnamese pig groups in Central Highland including Vietnamese domestic pigs, Vietnamese wild boars of group I and Vietnamese wild boars of group II. Single nucleotide polymorphism of cytochrome $b$ gene was applied to analyze the genetic relationship within these Vietnamese domestic pigs and wild boars and other wild boars. Cytochrome $b$ gene contains four single nucleotide polymorphism located at positions 15036 (T/C), 15038 (G/A), 15041 (C/T) and 15045 (G/A) of the pig mitochondrial DNA. The E1 (TGCG) and the E2 (TGTG) haplotypes are Europe, whereas the A1 (CATA) and the A2 (CATG) haplotypes have an Asian origin [12]-[15]. In this study, there were no Europe halotype distribution in Vietnamese wild boars and domestic pigs in the Central Highlands. A1 and A2 haplotypes (10 and 7 animals, respectively) were found in Vietnamese domestic pigs, four A1 haplotypes and five A2 haplotypes were found in Vietnamese wild boars of group II. Moreover, the phylogenetic tree demonstrated that Vietnamese wild boar of group I and domestic pigs located in A1 clade, suggesting that these wild boar and domestic pigs could have common ancestor with A1 haplotype. The A3 (TATG) haplotype was distributed in all Vietnamese wild boars of group I. However, the Vietnamese wild boars of group I were grouped in one clade, suggesting that Vietnamese wild boars of group I were genetically distinct from Vietnamese domestic pigs and wild boars of group II.

Using a molecular clock equation $(\lambda=d / 2 t)$; where $\lambda=$ substitution rate/site/year, $d=$ mean distance between individuals within groups or mean distance between groups and $t=$ divergence time), the above distances and employing the substitution rate $\left(1 \times 10^{-8}\right.$ substitution/site/year) for cytochrome $\mathrm{b}$ in mammalian species [16]. The European-Asian wild boar divergence is estimated to have occurred 500000 YBP [12] or 746000 YBP [17]. Here we found that the Vietnamese wild boars of group II have latest diverged from Asia wild boars (28000 YBP). The Vietnamese domestic pigs and Vietnamese wild boars of group I were earlier diverged than Vietnamese wild boars of group II (70500 YBP and 385500 YBP). The genetic diversity between Vietnamese wild boars of group I and group II and domestic pigs would reflect genetic differences of the ancestor population. Moreover, the divergence time between Vietnamese wild boar of group I and European wild boar is 421500 YBP. Therefore, the European wild boars and the Vietnamese wild boars of group I could have common ancestor.

In this study, the Vietnamese wild boars of group I were derived from the primeval forest in Bidoup-NuiBa national park and there was no crossbreeding between Vietnamese wild boars of group I and other wild boars. Therefore, Vietnamese wild boars of group I were a natural population that became isolated from other wild boars. The Vietnamese wild boars of group II and domestic pigs were collected from different areas in the Central Highlands. They were crossbred for production in various husbandry farms. The inter-specific or intra-specific hybridization of an invasion population with native or non-native populations would generate novel genotypes [18]. Thus, this showed that these indigenous pigs exhibited a high degree of cytochrome b variability, as described previously [19] and demonstrated using D-loop region [8]. However, the wild boars of these studies were collected from markets or hunters and they did not obtain any morphometric information of these wild boars. The morphological and genetic characteristics of Vietnamese wild boars are relatively little known [8]. In this study, we collected alive wild boars or domestic pigs from various areas and continue breeding them in Institute of Tropical Biology, Ho Chi Minh City. The present findings indicated that the Vietnamese domestic pigs in Central Highland were found to be genetically close to other domestic pigs and wild boars of Asia. The Vietnamese wild boars were separated into group II which was genetically close to Asian wild boars and group I which was genetically distinct to Asian wild boars. Since there were at least two types of haplotype of Vietnamese domestic pigs and three types of haplotype of Vietnamese wild boars in Central Highlands, Vietnam Central Highlands could be one of the most abundant sources for research on Asian wild boar and domestic pig populations.

\section{Acknowledgements}

This study was supported by “Vietnam Central Highlands 3rd Program” from Vietnam Academy of Science and Technology.

\section{References}

[1] Branicki, W., Kupiec, T. and Pawlowski, R. (2003) Validation of Cytochrome b Sequence Analysis as a Method of 
Species Indentification. Journal of Forensic Sciences, 48, 83-87.

[2] Clop, A., Amills, M.M., Noguera, J.L., Fernandez, A., Capote, J., Ramon, M.M., Kelly, L., Kijas, J., Andersson, L. and Sanchez, A. (2004) Estimating the Frequency of Asian Cytochrome B Haplotypes in Standard European and Local Spanish Pig Breeds. Genetics Selection Evolution, 36, 97-104. http://dx.doi.org/10.1186/1297-9686-36-1-97

[3] Larson, G., Dobney, K., Albarella, U., Fang, M., Smith, E.M., Robins, J., Lowden, S., Finlayson, H., Brand, T., Willerslev, E., Conwy, P.R., Andersson, L. and Cooper, A. (2005) Worldwide Phylogeography of Wild Boar Reveals Multiple Centers of Pig Domestication. Science, 307, 1618-1621. http://dx.doi.org/10.1126/science.1106927

[4] Alves, E., Óvilo C., Rodríguez, C. and Silió, L. (2003) Mitochondrial DNA Sequence Variation and Phylogenetic Relationships among Iberian Pigs and Other Domestic and Wild Pig Populations. Animal Genetics, 34, 319-324. http://dx.doi.org/10.1046/j.1365-2052.2003.01010.X

[5] Kim, K.I., Lee, J.H., Li, K., Zhang, Y.P., Lee, S.S., Gongora, J. and Moran C. (2002) Phylogenetic Relationships of Asian and European Pig Breeds Determined by Mitochondrial DNA D-Loop Sequence Polymorphism. Animal Genetics, 33, 19-25. http://dx.doi.org/10.1046/j.1365-2052.2002.00784.x

[6] Mona, S., Randi, E. and Ponzetta, M.T. (2007) Evolutionary History of the Genus Sus Inferred from Cytochrome b Sequences. Molecular Phylogenetics and Evolution, 45, 757-762. http://dx.doi.org/10.1016/j.ympev.2007.05.025

[7] Thuy, N.T.D., Melchinger-Wild, E., Kuss, A.W., Cuong, N.V., Bartenschlager, H. and Geldermann, H. (2006) Comparison of Vietnamese and European Pig Breeds Using Microsatellites. Journal of Animal Science, 84, 2601-2608. http://dx.doi.org/10.2527/jas.2005-641

[8] Ishiguro, N., Sasaki, M., Iwasa, M., Shigehara, N., Hongo, H., Anezaki, T., Long, V.T., Lan, D.T.B. and Long, P.T. (2008) mtDNA Variation in Vietnamese pigs, with Particular Emphasis on the Genetic Relationship between Wild Boars from Vietnam and the Ryukyu Islands. Mammal Study, 33, 51-68. http://dx.doi.org/10.3106/1348-6160(2008)33[51:MVIVPW]2.0.CO;2

[9] Wu, G.S., Yao, Y.G., Qu, K.X., Ding, Z.L., Li, H., Palanichamy, M.G., Duan, Z.Y., Li, N., Chen, Y.S. and Zhang, Y.P. (2007) Population Phylogenomic Analysis of Mitochondrial DNA in Wild Boars and Domestic Pigs Revealed Multiple Domestication Events in East Asia. Genome Biology, 8, R245. http://dx.doi.org/10.1186/gb-2007-8-11-r245

[10] Maniatis, T., Sambrook, J. and Fritsch, E.F. (1982) Molecular Cloning, a Laboratory Manual. Cold Spring Harbor Laboratory, Cold Spring Harbor, New York.

[11] Fernández, A.I., Alves, E., Fernández, A., de Pedro, E., López-García, M.A., Ovilo, C., Rodríguez, M.C. and Silió, L. (2008) Mitochondrial Genome Polymorphisms Associated with Longissimus Muscle Composition in Iberian Pigs. Journal of Animal Science, 86, 1283-1290. http://dx.doi.org/10.2527/jas.2007-0568

[12] Giuffra, E., Kijas, J.M., Amarger, V., Carlborg, O., Jeon, J.T. and Andersson, L. (2000) The Origin of the Domestic Pig: Independent Domestication and Subsequent Introgression. Genetics, 154, 1785-1791.

[13] Tamura, K., Peterson, D., Peterson, N., Stecher, G., Nei, M. and Kumar, S. (2011) MEGA5: Molecular Evolutionary Genetics Analysis Using Maximum Likelihood, Evolutionary Distance, and Maximum Parsimony Methods. Molecular Biology and Evolution, 28, 2731-2739. http://dx.doi.org/10.1093/molbev/msr121

[14] Saitou, N. and Nei, M. (1987) The Neighbor-Joining Method: A New Method for Reconstructing Phylogenetic Trees. Molecular Biology and Evolution, 4, 406-425.

[15] Jones, G.F. (1998) Genetic Aspects of Domestication, Common Breeds and Their Origin. In: Rothschild, M.F. and Ruvinsky, A., Eds., The Genetics of the Pig, CAB International, Wallingford, 17-50.

[16] Brown, W.M., George, M. and Wilson, A.C. (1979) Rapid Evolution of Animal Mitochondrial DNA. Proceedings of the National Academy of Sciences of the USA, 76, 1967-1971. http://dx.doi.org/10.1073/pnas.76.4.1967

[17] Fernández, A.I., Alves, E., Óvilo, C., Rodríguez, M.C. and Silió, L. (2010) Divergence Time Estimates of East Asian and European Pigs Based on Multiple near Complete Mitochondrial DNA Sequences. Animal Genetics, 42, 86-88. http://dx.doi.org/10.1111/j.1365-2052.2010.02068.x

[18] Lee, C.E. (2002) Evolutionary Genetics of Invasive Species. Trends in Ecology Evolution, 17, 386-391. http://dx.doi.org/10.1016/S0169-5347(02)02554-5

[19] Hongo, H., Ishiguro, N., Watanobe, T., Shigehara, N., Anezaki, T., Long, V.T., Binh, D.V., Tien, N.T. and Nam, N.H. (2002) Variation in Mitochondrial DNA of Vietnamese Pigs: Relationships with Asian Domestic Pigs and Ryukyu Wild Boars. Zoological Science, 19, 1329-1335. http://dx.doi.org/10.2108/zsj.19.1329 
Scientific Research Publishing (SCIRP) is one of the largest Open Access journal publishers. It is currently publishing more than 200 open access, online, peer-reviewed journals covering a wide range of academic disciplines. SCIRP serves the worldwide academic communities and contributes to the progress and application of science with its publication.

Other selected journals from SCIRP are listed as below. Submit your manuscript to us via either submit@scirp.org or Online Submission Portal.
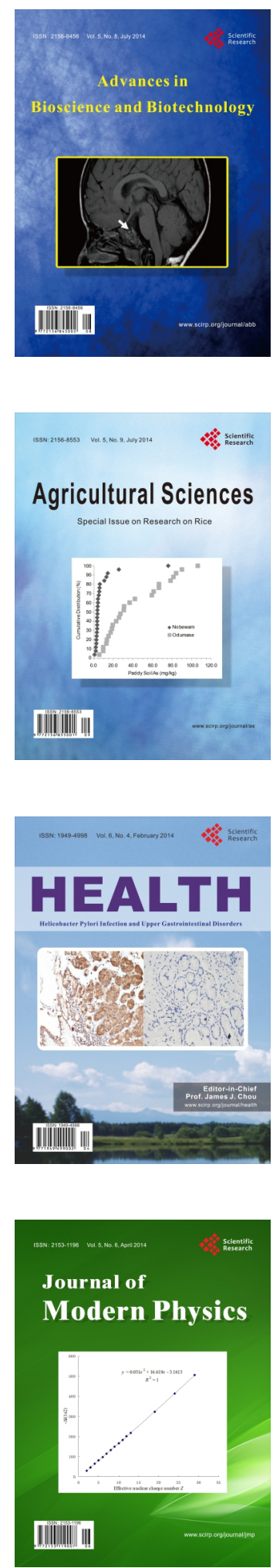
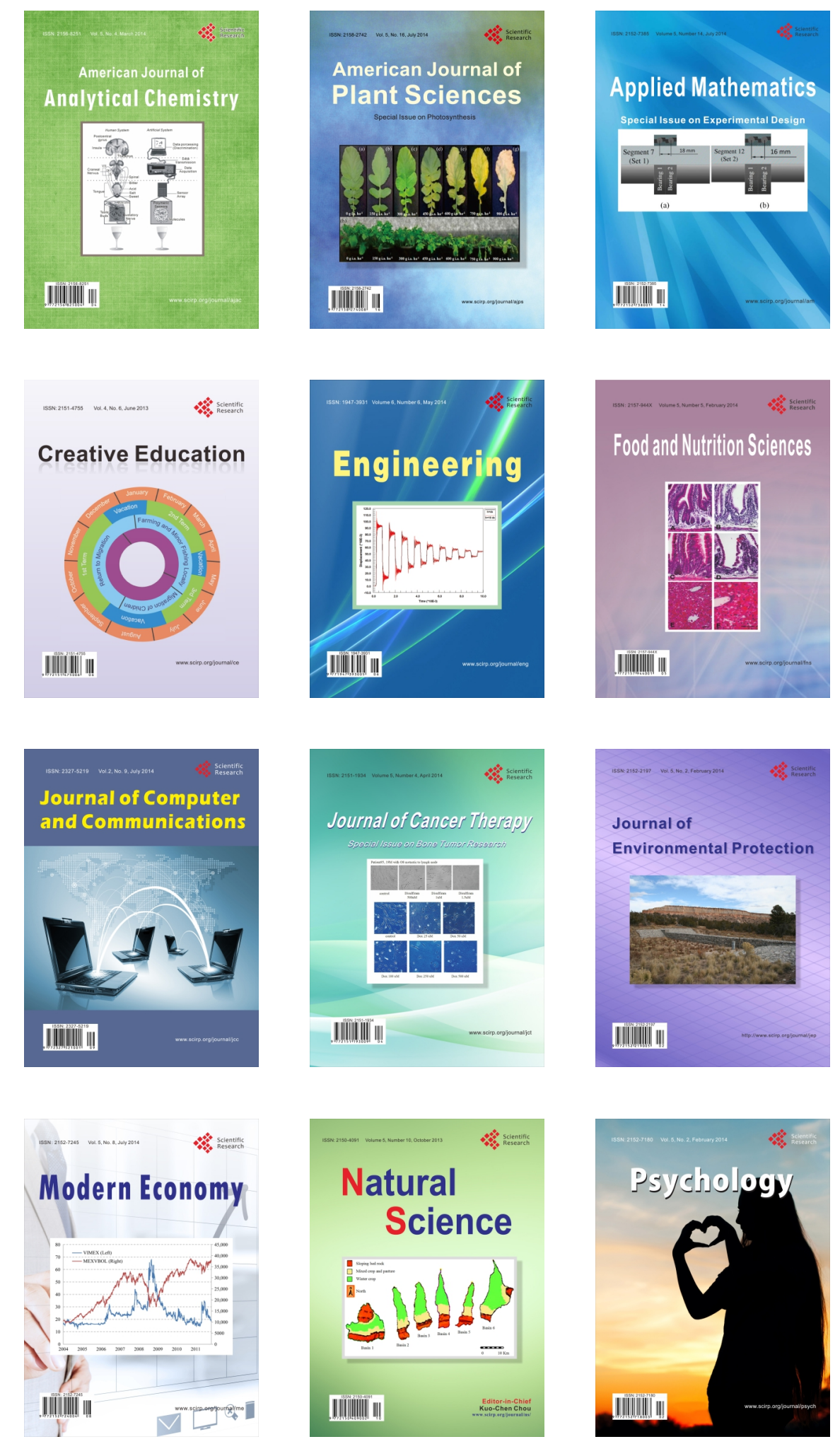